\title{
4. The media and
}

\section{journalism challenges}

in Melanesia

\section{Addressing the impacts of external and internal threats in Fiji, Papua New Guinea, the Solomon Islands and Vanuatu}

\begin{abstract}
This article advances discussions on media freedom and media development in Melanesia through the introduction of an 'external' and 'internal' threats analytical framework. Singling out the challenges and categorising them into these two main groups provides a clearer picture of the issues at stake, the links between them, and the need to address the situation holistically. External threats emanating from outside the media sector are often seen as more serious, and they often overshadow internal threats, which come from within the media sector. This article argues that both sets of threats have serious impacts on media and journalism in their own ways, and that both should be regarded equally. Furthermore, the linkages between these threats mean that one cannot be properly addressed without addressing the other. A key outcome of this discussion is a clearer understanding of how little control the media have over both external and internal threats, and how stakeholder support is needed to overcome some of the issues. Because good journalism benefits the public, this article argues for increased public support for high-quality journalism that delivers a public benefit.
\end{abstract}

Keywords: culture, external threats, Fiji, internal threats, media law, Melanesia, Melanesia Media Freedom Forum, Papua New Guinea, social media, Solomon Islands, Vanuatu

\section{SHAILENDRA B. SINGH}

The University of the South Pacific, Fiji

\section{Introduction}

-HIS article assesses the shifting media landscapes in four Melanesian countries-Fiji, Papua New Guinea, the Solomon Islands and Vanuatuand the many effects on journalism, including media freedom. The nu- 
merous media constraints in these developing nations are both historical and contemporary, and they have been analysed before (International Federation of Journalists, 2015; Robie, 2014; Singh, 2017; Tacchi et al., 2013). This article advances the discussions through a new approach by dividing the major media sector challenges into two sub-categories - external and internal threats. External threats emanate from outside the media sector, and internal threats come from within the sector. While the media in the four countries have been grappling with these threats for decades, there has been little progress in addressing some of the core issues, largely because of their complex characteristics. These range from autocratic-minded governments and a lack of resources, to inexperienced and underqualified journalists, and high staff turnover (International Federation of Journalists, 2015).

The purpose of applying a categorisation of external and internal threats is to identify, isolate and differentiate between the major challenges, as well as draw out the links between them, in clear fashion. This is important for various reasons, the main one being that internal threats, due to their covert nature, are often overshadowed by external threats, which are more overt. Internal threats, such as the often weak financial position of some news media organisations, and the lack of journalist capacity, are seen as more benign and less urgent than external threats such as government pressure and/or harsh media legislation (see Singh, 2017). This article argues that downplaying the internal threats is counterproductive since they are a serious impediment to media freedom and media development in their own ways. Furthermore, the two sets of threats may be different in nature and manifestation, but they are inextricably linked, and feed off each other. For instance, neglecting internal threats could mean strengthening the external threats. The specifics are discussed later in the article. At this point, suffice it to say that this understanding is crucial for capturing the essence of the problems in the Melanesian media sector, and examining/addressing them in a wholesale manner.

Although some threats are country-specific, the others have common traits across the Melanesian sub-region, with similar impacts on media development and media freedom. For instance, an International Federation of Journalists report on Papua New Guinea, the Solomon Islands and Vanuatu found that despite legal protections, media workers in all these countries faced the risk of threats and/ or assaults from police and politicians (International Federation of Journalists, 2015; also see Melanesia Media Freedom Forum, 2019).

This article revisits a published discussion paper that linked and analysed the key media developments in Fiji, Papua New Guinea, the Solomon Islands and Vanuatu in relation to policy, politics, free speech and good governance (Singh, 2017). Using 2015 as the case year, the discussion paper found hardening government attitudes towards the news media across the four countries, largely 
over editorial differences (Singh, 2017). All four Melanesian governments made fresh calls on the media to focus on a developmental, nation-building role, rather than apply the classical watchdog model, which they denounced as overly negative. On the other hand, media advocacy groups and the news media sector emphasised the importance of media's watchdog role in good governance. This longstanding ideological divide underpinned the tensions between the government and the news media sector in the four countries. Another key source of the increased hostilities was social media and citizen journalism, a fairly new phenomenon in the region (Singh, 2017).

The governments in the four countries were not just alarmed by the increased public criticism on cyberspace, but also the proliferation of inflammatory and abusive material, and the potential impact on their small and fragile societies. Governments appeared unable to cope with the increased volume of both social media and news media scrutiny, and they reacted by proposing harsher controls (Singh, 2017). The mainstream media became caught in the crossfire because of the overlap with social media. This trend indicated that while social media was initially hailed, globally, as a democratiser, it also had some anti-democratic effects that had started to surface around the world, including Melanesia (Alejandro, 2010; Melanesia Media Freedom Forum, 2019).

This article reexamines some of the findings of the 2017 discussion paper under the 'internal' and 'external' threats framework. The article considers recent developments in the four countries' media sectors, gleaned from news reports and academic literature, including the outcome document from the historic Melanesia Media Freedom Forum conference at Griffith University, Brisbane, in November 2019. Based on the research tabled at the conference, and journalists' first-hand accounts, the Forum made specific calls on Papua New Guinea to include journalists in anti-corruption and whistleblower protection legislation, and on Fiji to repeal the punitive 2010 Media Industry Development Decree. The Vanuatu government was asked to end attacks against its national media association, and the Premier of Western Province in the Solomon Islands was urged to cease his threats against local news organisations (Melanesia Media Freedom Forum, 2019).

The Melanesia Freedom Forum's outcome document indicates a continuing trend of growing government hostility towards both social media and mainstream news media, with increased concerns about a further shrinking of space for public discourse, and the impacts on freedom of speech (Melanesia Media Freedom Forum, 2019). While a certain level of government-media conflict is normal, even healthy, things can get out of hand if governments retaliate with legal sanctions that stifle legitimate journalism. This seems to be the trend in Melanesia, according to the literature (Melanesian Freedom Forum, 2019; Singh, 2017).

This article emphasises that despite some major weaknesses, the Melanesian news media remain important pillars of democracy, and they ought to be 
strengthened as part of the national accountability systems framework, especially in a region where corruption is a major problem (see Larmour, 2012). Because journalism serves the public interest, the strengthening of the media sector should be a shared responsibility, rather than shouldered by the media sector alone. Due to the revenue challenges caused by the digital disruption, the Melanesian media sector requires the support of all the stakeholders to grow and survive. This article argues that without additional support from governments, civil society, the private sector and international donors, journalism in Melanesia will continue to struggle and underperform. An important step towards strengthening journalism is a proper understanding of the nature of the problems. This is discussed in the next section, through 'external' and 'internal' threats framework.

\section{External and internal threats}

The major sources of the external threats include government, non-government sectors, foreign interests and society at large. Besides the ruling national power, government includes the various state ministries, departments, subsidiaries, proxies and representatives, whereas non-government sources include the corporate and non-corporate sectors. Foreign interests include foreign governments and foreign non-government entities, with diplomatic and or business ties in Melanesia (Melanesia Media Freedom Forum, 2019; Singh, 2017).

The literature indicates that the most common external threat is direct government threats across Melanesia (International Federation of Journalists, 2015; Melanesia Media Forum, 2019; Robie, 2014; Singh, 2017; Tacchi et al., 2013). Direct threats can be both coercive and non-coercive. Coercive threats usually emanate from disputes over the subject or angle of news reporting that cast government in a negative light. Reprisals that can range from a stern dressing down to the implementation of stronger media legislation, and/or warnings, as well as the occasional assault by the security forces. Even though not all the threats are always followed through, they contribute to the stresses of the profession (International Federation of Journalists, 2015; Melanesia Media Forum, 2019; Robie, 2014; Singh, 2017; Tacchi et al., 2013).

The non-coercive external threats include inducements such as government advertising contracts, which could act as a leverage to influence news coverage, especially in the Pacific, where both advertising sources and revenue are limited. The state, as a central player in the small Pacific economies (see Chen \& Singh, 2017; Chen et al., 2020) becomes a major advertiser through the various ministries, state corporations and other state-linked enterprises.

Besides the state, the private corporate sector is the other major source of external pressure, largely due to its disproportionately strong advertising clout in the small advertising markets of Melanesia.

The other type of external threat, social and cultural pressure, are prevalent 
in Melanesia due to communal group affiliations and kinship ties which link the small communities in various ways. Besides community pressure, there is pressure from the traditional power structures, such as the chiefly system in Fiji and the 'big man' culture elsewhere in Melanesia (Robie, 2014; Singh, 2018). According to a senior Papua New Guinean journalist Jean Morea, the 'Big Man Mentality' is a culture which restricts the ability of journalists to challenge or ask tough questions of people in power or respectable positions in society (Shaligram, 2019).

Robie (2019) has conceptualised this challenge through his talanoa journalism concept based on a five-legged tanoa framework. The tanoa is a bowl used for sharing traditional kava when engaged in discursive talanoa, or informal deliberation. Besides the four estates of a normative democratic structure - Executive, Parliament, Judiciary, Media (Press) - Robie's 'Pacific way' model also has a fifth leg/estate: Cultural hegemony, representing Indigenous tradition. Pacific journalists face a constant battle negotiating cultural obligations with the demands of contemporary journalism (Robie, 2019).

The prevalence of direct government threats in all four Melanesian countries indicates why these types of external threats attract the most attention. A sample of such threats in the 2017 discussion paper are revisited to understand their nature and their potential impact.

In the Solomon Islands, the then Prime Minister Manasseh Sogavare used his parliamentary address to warn of stronger media legislation, stating that without checks on bad reporting, the country risked creating a society with no respect for authority. He vowed to root out government whistleblowers (Singh, 2017). Sogavare's concerns about media breaches aside, the motives behind punitive legislation and their impacts are always questionable from censorship and good governance perspectives.

In Fiji, The Fiji Times faced flak from the two most powerful men in the country-Prime Minister Voreqe Bainimarama and Attorney-General Aiyaz Saiyed Khaiyum - over its reporting of government plans to prioritise rural students at state boarding schools and an opinion poll indicating some public disdain about government plans to redesign the national flag. Opposition leader Ro Temumu Kepa alleged that the boarding school decision was a move to 'weaken' the indigenous community, and warned of a push back (Singh, 2017). Bainimarama not only accused Kepa of ethnicising the issue, he also blamed the Times of colluding with her:

The Fiji Times also stands condemned for yet another grossly irresponsible piece of journalism. Rather than report dispassionately and in the interests of national stability, The Fiji Times is controlled by a cabal that manipulates the news agenda and uses inflammatory language to create disunity, division and instability and to advance its own political interests. (quoted by Singh, 2017) 
On his part, Khaiyum questioned the methodology of a Times-commissioned Tebbutt Research poll showing that 86 percent of Fijians preferred a vote on whether the national flag should be re-designed (Swami, 2015). The Times editor-in-chief, Fred Wesley, stood by the poll. He further clarified that while the newspaper did not necessarily share Kepa's opinion, it was still obliged to report it (Singh, 2017). Ordinarily, media would be expected to take such criticism in their stride, but Fiji's punitive media decree had amplified the risks, resulting in a confused and cagier media, as noted by a former Fiji journalist, Ricardo Morris (2015):

Do we continue to report views and issues critical of the government-no matter how constructive - and risk a breach that could potentially land an editor or journalist with a fine of up to $\$ 10,000$ and/or up to two years in jail, and the media company a fine of up to $\$ 100,000$ ? Or do we adopt pragmatism and self-censorship and live another day? (Morris, 2015, p.36)

While the two-year prison terms and FJ $\$ 1000$ fines stipulated for journalists were removed from the media decree in July 2015, the penalties for editors and publishers remain intact. This could mean that the publishers and editors would continue to censor newsrooms to avoid the risk of incriminating themselves.

In Vanuatu, a photographer covering a bribery scandal involving 14 MPs was bashed by one of the accused - the then Minister of Foreign Affairs, Serge Vohor. Reports stated that instead of stopping Vohor, police at the scene advised the photographer to file a formal complaint (Singh, 2017). In recent years, there have been several reports of assaults on journalists in Vanuatu. Such assaults highlight the vulnerability of journalists and sense of impunity exercised by certain powerful individuals in Melanesian societies as part of the 'big man' culture.

\section{External pressure from foreign sources}

Besides threats from their own governments, the Melanesian media face an emerging external challenge from beyond their borders, which has come into greater prominence in recent years. This relates to the apparent attempts by some foreign countries and foreign commercial interests to influence local media coverage of certain issues. These foreign entities often have diplomatic ties or business interests with the Melanesian countries. The pressure on the media could be exerted in connivance with the host countries' national government or state officials. Often, the aim is to either keep the media at bay, or to shape the coverage in a certain way with the 'growing influence of authoritarian and secretive values' (Robie, 2020). This form of pressure has become more frequent and more noticeable recently, with some well publicised incidents involving China and Indonesia. The incidents coincide with these Asian nations' increased geopolitical maneuvers and business investments in the region. 
A recent example involved the Vanuatu Daily Post news director, Dan McGarry, over a story in the 6 June 2019 edition of the paper on the arrest of six Chinese nationals in Vanuatu, by Chinese and Vanuatu police. Without access to the Vanuatu courts, the detainees were flown to China. McGarry's story highlighted this as an example of Chinese law being enforced in Vanuatu, raising questions about sovereignty issues. Following publication, McGarry was summoned by the Vanuatu Prime Minister, and told that he was being too negative, and, 'if you don't like it here, you can go home' (Galloway, 2019). Originally from Canada, McGarry is married to a Vanuatu citizen and has lived in the country for 16 years, but this did not stop the government from barring him from re-entering the country. While a court order reversed the decision, the incident highlighted China's influence over some Pacific Island governments, and the subsequent threat to news media (Galloway, 2019).

Another incident in PNG in June 2015 involved a 'fishy' US\$95 million Chinese deal to build the southern hemisphere's largest tuna processing hub in Madang. In response to growing community opposition and increased media scrutiny into the project's environmental impact, the government took out a restraining court order. The media advocacy group Pacific Freedom Forum saw the court order as an attempt to gag the media and concerned citizens, describing it as 'striking at the heart of democratic rights' (Pacific Freedom Forum, 2015).

In the Solomon Islands, the carefully-controlled visit of the Indonesian Foreign Minister, Retno Marsudi, drew the media's ire, with veteran journalist Ofani Eremae claiming that the government was shielding her from media questions about West Papua (Singh, 2017). Historically, the Melanesian countries have supported a free West Papua, and some observers saw the Marsudi visit as a move to "scuttle Melanesian recognition of Papua as [an] 'Occupied State"" (Jakarta Globe, 2015). The Solomon Islands' action during the Marsudi visit drew attention to the strong lobbying by Indonesia throughout Melanesia. This includes military support to Fiji after the 2006 coup, and significant aid to Papua New Guinea. With these countries' support, Indonesia was granted observer status in the Melanesian Spearhead Group in 2011 (Blades, 2011). The continued national media support for a free West Papua would conflict with the national governments' changing priorities on the issue.

Another example of external threat in Fiji in 2019 involved a private Chinese company, Freesoul International. Three New Zealand journalists investigating allegations of extensive environmental damage in a tourism project on Malolo Island were arrested and detained overnight at a local Fijian police station (Radio New Zealand International, 2019). Extensive international coverage saw to the release of the journalists, followed by a personal apology from Prime Minister Bainimarama, with the arrest blamed on 'rogue' policemen. The company was eventually charged, and its licence revoked, but not before another outcry over a 
court official asking local reporters to leave the courtroom during a proceeding in Nadi. The court official claimed to be acting on the magistrate's orders (Nasiko, 2020; Radio New Zealand International, 2019).

It should be noted that to a large extent, the external threats are beyond the control of the media sector and its responses to date have been limited, if not muted on some occasions. For instance, media react to government threats by ignoring them, or with a rebuttal, in the hope of setting the record straight, and winning some public support. With regard to the use of advertising to influence media, at least some media are deemed susceptible to the overtures from both the state and the private sector due to their low and limited financial base, although more research is required in this area to obtain a clearer understanding of the situation (see International Federation of Journalists, 2015; Robie, 2014; Singh, 2017; Tacchi et al., 2013).

\section{Social media - both a threat and an asset}

More recently, social media has emerged as a major challenge and potential game changer for the news media sector across Melanesia, both in positive and negative ways. The 2017 discussion paper on Melanesian media indicated that mainstream media in all four countries have borne the brunt of both social medias' democratising and anti-democratising impacts. Social media, including citizen journalism, support and strengthen traditional journalism, but also weaken it by diverting away revenue. There is, as Robie indicates (2020), a 'growing tendency for Pacific governments to use unconstitutional, bureaucratic or legal tools to silence media and questioning journalists'. In Melanesia, the government crackdown on social media abuse has repercussions for the news media (Singh, 2017; Tarai, 2019).

While governments could be accused of censorship, they have some real concerns about social media abuse, and the damage to individuals, communities and society. These concerns are shared by the public. Fiji's Online Safety Act implemented in January 2019 to address cyber stalking, cyber bullying, revenge porn and internet trolling had a measure of public support (Tarai, 2019). However, there were also concerns about the restrictions on freedom of speech under the guise of protection against malicious acts. In Fiji, social media is seen as an important avenue for uncensored information in the context of country's restricted media landscape (Tarai, 2019).

In Papua New Guinea, the then Peter O'Neil-led government had warned of banning Facebook and other social media, claiming that 'fake news' was destroying the country. Similar views were expressed by some members of the public. Papua New Guinea national rugby league chief executive Brad Tassell, while resigning in March 2015 over a torrent of defamatory allegations online, described the social media scene as 'literally out of control' (Singh, 2017). 
However, civil society organisations called for measured government response given the country's corruption problem and the fact that social media platforms like Facebook and Twitter had become an 'essential check and balance' on the abuse of power (Singh, 2017). During this controversy, O’Neill was dogged by allegations of corruption and faced a no-confidence motion, forcing his resignation in May 2019. Since then, the social media controversy has receded to the background, but it could well reemerge, with continued internet penetration, ongoing scrutiny and criticism of the government, and a fair share of online media abuse (Melanesia Media Freedom Forum, 2019).

The 2017 discussion paper indicated that Vanuatu and the Solomon Islands also face threats of legislation (Singh, 2017). In Vanuatu, the government had warned of a law to curb 'excessive liberty', including unsubstantiated allegations and abusive comments on radio talkback shows. The then Prime Minister Sato Kilman accused the Yumi Toktok Stret Facebook group of 'inciting social anarchy and instability', adding that the wrong use of media could 'easily destabilise' peace and order (Singh, 2017). The current Vanuatu Government is working with the Australian Government and the Council of Europe on a cybercrime bill to target 'false claims' on social networking sites such as Facebook, which were 'out of control' (Kant et al., 2018).

In the Solomon Islands, threats of legislation have been growing since 2015, with the then Prime Minister, Sogavare, singling out the watchdog group, Forum Solomon Islands International, for alleged inaccurate statements. Since the 2014 election, the blog had highlighted what it saw as rampant government malpractice, with claims that corruption had 'gone viral'. But Sogavare dismissed the group as a 'listed charity' interfering in national politics (Singh, 2017). The Director of Public Prosecution, Ronald Bei Talasasa, has stated that legislation is needed to overcome cybercrime and to control Facebook, where '...people are just running free' (Kant et al., 2018).

The summary of external threats explains why they are at the forefront of discussions about media freedom, but internal threats pose major difficulties as well. This is covered in the following section.

\section{Internal threats}

Internal threats emanating from within the news media sector include longstanding, unaddressed issues such as underqualified and inexperienced journalists, uncompetitive salaries, high journalist turnover and some media companies' often weak financial positions, largely due to the small advertising markets. For example, the International Federation of Journalists (2015) report on Papua New Guinea, the Solomon Islands and Vanuatu found a relatively youthful, inexperienced and underqualified journalist corps, who were among the lowest paid employees in their countries. Internal threats are the apparent 
causes of what some critics describe as poor journalistic standards, including lack of knowledge about political and social institutions, questionable grasp of ethics and poor understanding of complex issues (Robie, 2014).

Internal weaknesses that hinder the media's ability in public interest reporting are contained in two separate studies on Fiji and Papua New Guinea (Larson, 2008; Lasslett, 2015). The Fiji study observes a fairly heavy media dependence on the government as a news source. This is regarded as a threat to the media's watchdog role (Larson, 2008). Similarly, the PNG study highlighted the alleged dearth of indepth journalism and it described the national media as an 'unfiltered communications mouthpiece' for government and corporate interests (Lasslett, 2015). The apparent reliance on media releases in both Fiji and Papua New Guinea could be a result of deadline pressures and/or a manifestation of inexperienced and under-qualified journalist corps' shying from complex reporting assignments. Whatever the reasons, the impact of internal threats on public interest reporting and the public right to know is undeniable. What is noteworthy is that the Fiji and PNG media sectors are the largest and most developed in Melanesia. This raises questions about the situation in the smaller island countries.

What this article has identified as internal threats are at the heart of government concerns about the media - alleged unprofessional practices and their impacts on society. Such concerns cannot be dismissed out of hand. Coronel (2001) has highlighted the antidemocratic tendencies of media, such as sowing fear, division and violence, particularly in fragile, developing states (Frohardt $\&$ Temin, 2003). Such threats pose the greatest danger in unstable countries susceptible to societal tensions. Melanesia has seen its fair share of internal conflicts in recent decades, with the media accused of fuelling some disputes through reckless, uninformed reporting (Iroga, 2008; Robie 2014).

The risks multiply in countries with underdeveloped media infrastructure. The journalists commit ethical breaches not necessarily because they are biased, but due to poor professional skills and other constraints. This is involuntary or passive incitement to violence (Frohardt \& Temin, 2003, p. 2). Under such circumstances, journalists could inflame grievances and promote stereotypes, even though their intentions are not malicious (Frohardt \& Temin, 2003, p. 2). This scenario indicates that the need to address internal threats is greatest in fragile societies because of the potential for damage.

Punitive legislation on its own does not address the internal threats that lead to poor reporting practices in the first place. It is now 10 years since the Fiji media decree was implemented to 'improve' professional standards, but the government still complains about poor reporting (Singh, 2018). If criticism of the Fiji media decree- that it has fostered self-censorship — are valid, then the Fiji trend of stronger legislation taking hold in Melanesia should be a concern. Punitive legislation could be a double blow for journalism if a cowed media 
go into self-censorship mode, with no discernible improvements in professionalism to boot. It could be a further strike against journalism if such legislation is a disincentive to join the profession because of the risks of fines and imprisonment; especially if the pool of journalists is small to begin with, as in Melanesia (see International Federation of Journalists, 2015; Tacchi et al., 2013).

Another internal threat is the media companies' commercial priorities and the effect on news coverage. The question is whether the pursuit of profits compromise and/or override editorial obligations and the public interest. In Fiji's case, the national newspaper, the Fiji Sun, is often accused of pandering to the government, which advertises exclusively in the newspaper (Morris, 2015). But the Sun insists that the advertising tender was won in a fair process.

Internal threats are largely being addressed by international aid agencies such as the latest Australian government-funded multi-million Pacific Media Assistance Scheme (PACMAS) to improve 'practitioners' capacity to report responsibly on key developmental issues'. But given the ad-hoc nature of donor funding and concerns about strings-attached media development aid, there needs to be greater local input and ownership (Robie, 2014).

Moreover, journalism is becoming tougher to support commercially, more so in the Pacific, and the media industry will need the sponsorship and support of governments, the private sector and other interested parties to achieve relevant, meaningful and sustainable change. Governments, especially, could do more than just implement punitive legislation. Governments could provide various subsidies for media organisations and increased scholarships for journalists to address the root causes of poor journalism, while keeping a respectable distance so as not to influence coverage.

The discussion on internal problems indicates that while such problems emanate from within the media industry, they are linked to the broader national factors in each of the four Melanesian countries. These include the relative smallness of the national economies, low disposable incomes, limited product sales and small profit margins. These conditions often leave little room for paying competitive salaries to retain journalism staff, or investing in staff development to improve news coverage and quality. In other words, the internal problems may be internal in name, and in nature, but they are not fully within the media sector's control, or of its making.

\section{The links between internal and external threats}

The literature indicates that much of the emphasis is on the external threats to media freedom, since they are considered more dangerous than internal threats. The overt and coercive nature of external threats, especially from governments, make them more visible, and give them a greater sense of immediacy and urgency. Because external threats often have stronger news elements of conflict, 
impact, and prominence-especially if the government is involved-such threats are deemed more newsworthy, and as a result, they receive greater media coverage. Moreover, external threats from governments also pose a danger to the news media's power and pecuniary interests by curbing their influence. As a result, such threats receive greater priority from the news media organisations, which mount a fight-back through the best means at their disposal—-the power to reach and influence the public.

Public awareness about internal threats is comparatively lower since the news media are less likely to carry regular reports about internal matters concerning journalists' working conditions, lack of training and qualifications, or their ethical and/or professional lapses. Besides reduced media coverage, internal threats receive less attention from civil society organisations when compared to external threats. This is because external threats are seen to pose a greater risk to ideals of civil society — good governance and civil rights.

Internal threats may also receive lower prominence in most reports, studies, conferences and statements, again because such threats are deemed less urgent and less damaging in the overall scheme of things. For example, the Melanesia Media Freedom Forum Outcome Statement (2019) had a clear focus on external threats. The statement is self-explanatory as to why external threats are often prioritised: not only is the list of external threats substantive, but they are quite serious in nature: intimidation, political and legal threats, police and military brutality, illegal detention, and violence against younger and female reporters. The statement did not address the core internal threats-journalists' working conditions, the low prospects for training and development, and the high turnover rate in newsrooms - in as much detail (Melanesia Media Forum, 2019).

While the emphasis on external threats is understandable, even justifiable, internal threats should not be played down. The strong connections between external and internal threats suggest that they both need to be addressed jointly to strengthen media freedom. External threats are the symptoms whereas internal threats are the root of the problem. For instance, both experience and qualifications are determinants of journalist professionalism. To a fairly large extent, retaining professional staff and building newsroom experience depends on salary and work conditions (notwithstanding the stress some tend to place on passion for journalism alone). Uncompetitive salaries mean that media companies are unable to retain staff. This leaves media companies in a perpetual struggle to build newsroom capacity, with staff leaving for better paid roles in the other fields of communication having to be replaced with new recruits. This scenario, which is being played out in the four Melanesian countries, affects the quality of journalism (International Federation of Journalists, 2015; Tacchi et al., 2013).

Poor journalism - the output of unaddressed internal threats - is government's main justification for stronger legislation. This exemplifies how out- 
standing internal threats give rise to external threats. This clear link should not be overlooked.

The more entrenched the internal threats become, the more they compound the external threats, especially if the public become disenchanted with the quality of journalism, and are pushed into the governments' arms with regards to harsher legislation. This situation is exemplified by an incident in PNG in 2015. One of the two national dailies, the Post-Courier, was accused of ethical breaches over a page one lead story on February 20 about illegal Asian prostitutes in the country when it emerged that the images in the story were not of local girls, but lifted from a Nigerian news website. Public anger was rampant on social media, with the newspaper accused of falsifying information for profit (Singh, 2017).

\section{Conclusion}

This review approached outstanding issues in the Melanesian media sector from the 'internal' and 'external' threats framework. Some historical issues have been compounded by the growing use and abuse of social mediadouble-edged sword that both helps and hobbles the practice of journalism in Melanesia (Singh, 2017).

This review identified the links between external threats, like government and corporate pressure, and internal threats, like the lack of journalist capacity. While external threats tend to overshadow internal threats, unresolved internal threats that lower professionalism pose major risks in their own right. For example, the media's heavy reliance on government and corporate press releases could be an outcome of internal threats or weaknesses that compromise the public right to know. This is also a curtailment of media freedom.

Governments favour punitive legislation to address the alleged lack of professionalism in the media corps. But this only treats the symptoms, not the root causes. Punitive legislation on its own does not address internal threats, like the lack of journalist, experience, qualification or uncompetitive salaries. To the contrary, punitive legislation could well exacerbate the problems by causing fear and worsening journalist attrition, besides stifling debate and encouraging bad governance.

The real challenge is to lift standards by addressing internal threats through a consistent programme of education and training, and by retaining staff through better salaries and working conditions. A system that produces a well-educated and a well-paid journalist corps is better at withstanding and staving off external threats like government pressure, and to rising up to emerging threats, such as the misinformation on social media, and attempts by foreign powers to influence reporting.

Granted that addressing internal threats is not a full-proof strategy against attacks on media freedom, unless governments are sincere. After all, governments are known to target media not just for not doing their work well, but also 
for doing it too well. However, a more professional workforce would be better able to face up to external threats from government and other sources. Moreover, such a professional workforce is more likely to have public support against government crackdowns compared to an unprofessional one.

\section{References}

Alejandro, J. (2010). Journalism in the age of social media. Reuters Institute Fellowship Paper. Oxford: University of Oxford.

Bilua, B. (2017, September 20). Solomon Islands vulnerable to cybercrime. Islands Sun. Retrieved from http://theislandsun.com.sb/solomon-islands-vulnerable-cyber-crime/

Blades, J. (2011, April 26). Fiji's military ruler uses Melanesian Spearhead Group to end pariah status. Guardian Online. Retrieved from https://www.theguardian.com/ world/2011/apr/26/melanesia-fiji-frank-bainimarama-blades.

Chen, H., \& Singh, B. (2017). Output impacts of the interaction between foreign direct investment and domestic credit: Case study of Pacific Island countries. Studies in Economics and Finance, 34(3), 331-343. https://doi.org/10.1108/SEF-02-2016-0044

Chen, H., Chand, S., \& Singh, B. (2020). Impact of remittances on private sector credit in the Pacific Island countries. Buletin Ekonomi Moneter Dan Perbankan, 23. https:// doi.org/10.21098/bemp.v23i0.1215

Coronel, S. (2001). The role of media in deepening democracy. Retrieved from http:// unpan1.un.org/intradoc/groups/public/documents/un/unpan010194.pdf

Frohardt M., \& Temin, J. (2003). Special report: Use and abuse of media in vulnerable societies. Washington, DC: United States Institute for Peace.

Galloway, G. (2019, November 18). Journalist says Vanuatu ban linked to China coverage. The Sydney Morning Herald. Retrieved from https://www.smh.com.au/politics/ federal/journalist-says-his-ban-from-returning-to-vanuatu-linked-to-china-coverage20191118-p53bn1.html

International Federation of Journalists. (2015). Strengthening media in the Pacific: Country situational reports from Papua New Guinea, the Solomon Islands and Vanuatu.

Iroga, R. (2008). Local media's role in peace building in post-conflict Solomon Islands. In E. Papoutsaki \& U.S. Harris (eds), South Pacific islands communication: Regional perspectives, local issues (pp. 152-74). Singapore: Asia Pacific Information and Communication Centre/Nanyang Technological University.

Jakarta Globe (2015, March 2). Retno rushes to scuttle Melanesian recognition of Papua as 'occupied state'. Retrieved from: https://jakartaglobe.id/news/indonesias-foreignminister-melanesian-shuttle-diplomacy/

Kant, R., Titifanue, J., Tarai, J., \& Finau, G. (2018). Internet under threat?: The politics of online censorship in the Pacific Islands. Pacific Journalism Review : Te Koakoa, 24(2), 64-83. https://doi.org/10.24135/pjr.v24i2.444

Larmour, P. (2012). Interpreting corruption: culture and politics in the Pacific Islands. Honolulu, HA: University of Hawai' $i$ Press.

Larson, E. (2008). Reproducing disengagement: citizens' orientations: the news media and democracy in Fiji. Fijian Studies: A Journal of Contemporary Fiji, 6(1\&2), 9-32.

Lasslett, K. (2015). The spin cycle: How Papua New Guinea's media washes dirty stories. International State Crime Initiative. Retrieved from http://statecrime.org/state-crimeresearch/spin-cycle-papua-new-guineas-media-washes-dirty-stories/

Melanesia Media Freedom Forum. (2019). Outcome statement. Retrieved from https://www. griffith.edu.au/_data/assets/pdf_file/0016/910123/MMFF-Outcome-Statement.pdf 
Morris, R. (2015). Fiji media regulation: Emerging from 'worst of times' to 'best of times'? Pacific Journalism Review : Te Koakoa, 21(1), 34-39. https://doi.org/10.24135/ pjr.v21i1.146

Nasiko, R. (2020, October 18). Freesoul International case: Media officials told to leave courtroom. The Fiji Times. Retrieved from https://www.fijitimes.com/freesoulinternational-case-media-officials-told-to-leave-courtroom/

Pacific Freedom Forum (2015, June 26). PNG courts must reject order against protest. Retrieved from https://pacificfreedomforum.blogspot.com/2015/06/

Radio New Zealand International (2019, April 4). Fiji PM apologises to NZ journalists detained in Fiji. Retrieved from https://www.rnz.co.nz/news/national/386287/fiji-pmapologises-to-nz-journalists-detained-in-fiji.

Robie, D. (2014). Don't spoil my beautiful face: Media, mayhem and human rights in the Pacific. Auckland, NZ: Little Island Press.

Robie, D. (2019). Karoronga, kele'a, talanoa, tapoetethakot and va: expanding millennial notions of a 'Pacific way' journalism education and media research culture. Media Asia. https://doi.org/10.1080/01296612.2019.1601409

Robie, D. (2020). Melanesian media freedom challenges: Climate crisis, internet freedoms, fake news and West Papua. Pacific Journalism Review : Te Koakoa, 26(1), 12-33. https://doi.org/10.24135/pjr.v26i1.1072

Shaligram, H. (2019, October 18). Papua New Guinea's untold media freedom challenge. The Interpreter. Retrieved from https://www.lowyinstitute.org/the-interpreter/ papua-new-guinea-s-untold-media-freedom-challenge

Singh, S. (2017). State of the media review in four Melanesian countries-Fiji, Papua New Guinea, Solomon Islands and Vanuatu - in 2015. SSGM Discussion Paper, 2017(1).

Singh, S. (2018). A year in the life of Fiji's beleaguered national news media: Insights from the 2016 state of the media report and some potential implications of 'development journalism'. Journalism, 1-18. https://doi.org/10.1177/1464884918774309

Swami, N. (2016, April 27). Opposition queries A-G. The Fiji Times Online. Retrieved on April 28, 2016, from http://www.fijitimes.com/story.aspx?id=351306

Tacchi, J., Horst, H., Papoutsaki, E., Thomas, V., and Eggins, J. (2013). PACMAS State of Media and Communication Report 2013. PACMAS/ABC International Development, Melbourne.

Tarai, J. (2019, January 21). Controlling the internet in Fiji. Devpolicy blog. Retrieved from https://devpolicy.org/controlling-the-internet-in-fiji-20190121/?utm source $=$ rss \&utm_medium $=$ rss \&utm_campaign $=$ controlling-the-internet-infiji-20190121

Dr Shailendra Singh is a Pacific Media Centre research associate and a senior lecturer and coordinator of journalism at the University of the South Pacific (USP) in Suva, Fiji, where he teaches print and online journalism, as well as media law and ethics. He holds a Master's in Business Administration (from USP), a Graduate Certificate in Tertiary Teaching, and a PhD from the University of Queensland. $\mathrm{He}$ is an experienced Fiji newspaper and magazine editor. His research focus is Melanesia and the wider Pacific region, in the areas of media development, media law, and conflict reporting.

shailendra.singh@usp.ac.fj 